\title{
O UPRZEDMIOTOWIENIU AUTORÓW, WSZECHWKADZY WYDAWCÓW I NĘDZY PRAWA AUTORSKIEGO \\ PRAWO AUTORSKIE W CZASACH RESTAURACJI KAPITALIZMU W POLSCE
}

I. Obnoszona na gospodarczym i przecież nie tylko cywilistycznym sztandarze zasada swobody umów, mimo swych oczywistych, w części nieuchronnych ograniczeń, na gruncie prawa autorskiego - w odniesieniu do przenoszenia praw do utworów naukowych - najczęściej bierze w łeb.

Umowy wydawnicze przekazywane są bowiem ich twórcom do podpisu, nie do pertraktacji, oczywiście już po podjęciu przez redakcję decyzji o publikacji. W przypadku publikacji pokonferencyjnych jest tak samo. Kontekst presji, pod jaką znajduje się autor niegodzący się na narzucane postanowienia umowne, jest jednoznaczny. W obu przypadkach może on odmówić zawarcia umowy, ponosząc konsekwencje: jego tekst tu, gdzie miał się ukazać, nie ukaże się, co niekiedy może oznaczać, że nie ukaże się nigdzie. W przypadku artykułu wygłoszonego na konferencji jego ogłoszenie w innym miejscu niż publikacja pokonferencyjna może być nierzadko bardziej utrudnione, jeśli bowiem kolejny edytor o wygłoszeniu wystapienia wie, zgłoszenie tego tekstu do publikacji nie w edycji pokonferencyjnej może wzbudzić jego istotne wątpliwości i zniechęcić do drukowania.

Prawie powszechna formuła narzucania autorowi treści umowy staje się szykaną wobec twórcy pracy naukowej i kpiną z prawa autorskiego, bo w gruncie rzeczy twórca, nie tylko rozpoczynający swą badawczą drogę, najczęściej nie ma warunków do swobodnej odmowy jej zawarcia. Poddany jest bowiem sytuacyjnej, zawodowej, niekiedy nawet życiowej presji i nieuczciwą umowę podpisuje. Wie także, że próba szukania innego, spolegliwego wydawcy jest nadzwyczaj trudna, jeśli nie mają być to edytorzy niszowi, których periodyki nie są objęte chorym, ministerialnym konceptem punktowania, zaimportowanym z jedynie słusznej strony świata.

Moja ocena dotyczy zarówno większości umów wydawniczych, jak i tych proponowanych rzekomo przez redakcje. Te drugie sa bowiem w istocie umowami kształtowanymi przez wydawcę, który chce sobie oszczędzić niewielkiej mitręgi związanej z przekazywaniem i odbieraniem umów zawartych z poszczególnymi autorami.

W umowach tych wydawcy gwarantują sobie najczęściej prawo do wszystkiego, nawet do tego, co niemożliwe. 
Mam przed sobą przesłane mi do podpisu kilkustronicowe, nadzwyczaj szczegółowe teksty umów licencyjnych oraz zgód na „przeniesienie autorskich praw majątkowych wraz z udzieleniem pełnomocnictwa". W jednej z nich wyrazić mam zgodę na wydanie przez XX mojego artykułu w książce zbiorowej, na zasadach uzgodnionych przez redaktora naczelnego YY $\mathrm{w}$ umowie przez nich zawartej, a nadto na zawarcie przez YY z XX umowy w moim imieniu. Lecz ani umowy zawartej już między XX i YY, ani projektu umowy, którą YY ma zawrzeć w moim imieniu z XX, w ogóle mi nie pokazano.

W przedstawianym mi do podpisu dokumencie stwierdzono, że w „szczególności wyrażam zgodę na przeniesienie na XX bezterminowo, na zasadzie wyłączności i w nieograniczonym zakresie autorskich praw majątkowych do [...]" utworu. Nie mam żadnej możliwości wyboru, zgoda ma być totalna: na zawsze, na wyłączność, bez ograniczeń. Bezterminowość mojego przeniesienia ma prawo zadziwiać tych, którzy wiedza, że autorskie prawa majątkowe sa ex lege terminowe, co skądinąd budzi mój odosobniony prawie w Polsce sprzeciw ${ }^{1}$.

Drugorzędne z tej perspektywy jest to, że określono mnie w tym dokumencie jako współautora utworu będącego zbiorem artykułów, choć artykuł napisałem sam, a współautorem książki, do której on wejdzie, nie jestem. Wskazano jednak tytuł tej książki, której współautorem rzekomo jestem, a o którym dowiedziałem się dopiero teraz, z niesmakiem, bo jest pretensjonalny i zawiera dziwaczny termin będący niewolniczą polską kalką wyrażenia obcego.

Mam wyrazić zgodę na opublikowanie swojego utworu „w dowolny sposób”, co w zasadzie eliminuje możliwość podnoszenia roszczeń, nawet gdyby ukazał się pisany od prawej do lewej i od dołu do góry. Godzę się też na to, że wydawca umieści mój utwór w bazach elektronicznych z możliwością udostępniania przez sieć internetowa „,bez ograniczen”, z czego wynika niby, że nie godzę się na to, aby wydawca jakiekolwiek ograniczenia wprowadzał, choć oczywiste jest dla mnie to, że intencją tego bełkotliwego zapisu było pozostawienie wydawcy swobody w udostępnianiu z ograniczeniami albo bez ograniczeń. Godzę się też na rozpowszechnianie egzemplarza utworu „na terytorium Rzeczpospolitej Polskiej oraz na terytoriach wszystkich innych państw”, co pocieszajace, bo wynika z tego, że nie wyrażam zgody na rozpowszechnianie na wodach międzynarodowych. I oczywiście nie w kosmosie.

Za swoją zgodę otrzymam honorarium, do odbioru którego upoważnić mam YY, choć nigdzie mnie nie poinformowano, jakie to honorarium będzie. Domyślam się, co nie świadczy o mojej inteligencji, że większy pieniądz to nie będzie. Jestem pewien, że hydraulik, którego wynajmuję, gdy w domu przecieka

${ }^{1}$ Nie błędność, ale moim zdaniem fałsz argumentacji, która ma uzasadniać czasowość autorskich praw majątkowych, szeroko przedstawiłem w artykule zatytułowanym Kapitalizm tak! Wypaczenia nie! czyli o rzekomo niewatpliwej ratio legis wygasania autorskich praw majatkowych, w: K. Szczepanowska-Kozłowska (red.), Oblicza prawa cywilnego. Ksiega jubileuszowa dedykowana Profesorowi Janowi Bteszyńskiemu, Warszawa 2013, s. 278 i n. Por. wezwanie do skrócenia czasu ochrony tych praw, z powołaniem się na rzekomy interes społeczny: J. Barta, R. Markiewicz, O potrzebie zmian prawa autorskiego, w: K. Szczepanowska-Kozłowska (red.), op. cit., s. 43 i n., w szczególności s. 50 i n., oraz S. Sołtysiński, O potrzebie reformy prawa własności intelektualnej (na marginesie uroczystości poświęconej setnej rocznicy urodzin Profesora Adama Szpunara), „Przegląd Prawa Handlowego” 2013, nr 9, s. 11 i n. 
kaloryfer, pokładałby się ze śmiechu, gdybym mu zaproponował taką zapłatę za dwa miesiące pracy, które przeznaczyłem na kwerendy, lektury i pisanie. W związku z tym, że jest jednak nadzieja na jakieś honorarium, wyrażam także zgodę i na to, aby wydawca przenosił moje autorskie prawa majątkowe oraz udzielał „wszelkiego rodzaju” licencji również odpłatnie. Jednego mogę być pewien: otrzymam jeden egzemplarz książki z moim artykułem, z zastrzeżeniem, że nie wolno mi go nikomu sprzedać. Dostanę więc nieco więcej niż uliczna dziewczyna z Acapulco, która za usługę bez konieczności korzystania z lokalu może liczyć na paczkę marlboro, z tym jednak, że jej prawo do odsprzedaży zarobionej paczki papierosów nie jest zapewne kwestionowane.

Dokument kończy ustanowienie YY moim pełnomocnikiem wobec XX, upoważnionym do zawarcia umowy, przyjmowania oświadczeń, wykonywania uprawnień, reprezentowania etc. A także do odebrania mojego wynagrodzenia w wysokości, której może dobrze, że nie znam.

Jasne jest dla obu stron takich i podobnych umów, że wydawca nie oczekuje ani nawet nie spodziewa się żadnych pertraktacji. Nie tylko z moich doświadczeń wynika, że próba jakiejkolwiek modyfikacji takich kontraktów jest najczęściej beznadziejna. Wiedząc o tym, podjąłem raz skuteczne starania o zmodyfikowanie tekstu umowy, w ten sposób, że w gęsto zapisanym drobnym drukiem wielostronicowym tekście umowy dopisałem również drobnym drukiem krótkie: „nie”. Najwyraźniej nikt tego nie zauważył, przeoczył w stosie takich samych umów, bo w ogóle nie spodziewał się, że jeden z kilkudziesięciu autorów uczyni cokolwiek innego poza sprawdzanym przez wydawcę podpisem ulokowanym na ostatniej stronie. Udało się.

Innym razem na pozór przegrałem, gdyż zaskoczony stanowczym postanowieniem umownym zakazującym mi publikowania kiedykolwiek i gdziekolwiek indziej artykułu, do którego publikacji przenosiłem prawa, zapytałem z głupia frant: Co z moim prawem do przyszłego opublikowania tego tekstu w zbiorze własnych artykułów? Odpowiedziano mi z powaga, że muszę się wówczas zwrócić z prośbą do wydawcy, który być może udzieli mi na to zgody, ostrzegając mnie jednocześnie, że próba umieszczenia przeze mnie takiego postanowienia w obecnej umowie spowoduje jej niepodpisanie przez wydawcę i nieopublikowanie zakwalifikowanego już do druku tekstu. Koniec końców z udawanym żalem zrezygnowałem z zabiegania o takie postanowienie $\mathrm{w}$ umowie, nie sugerując pani redaktor lektury art. 62 ust. 1 pr.aut., zgodnie z którym twórca „może w zbiorowej publikacji swych utworów umieścić utwory, o których publikację zawarł odrębną umowę", co jako ius cogens nie może być skutecznie unicestwione zobowiązaniem umownym. Choć zapewne tylko do czasu, gdy ten czy inny wydawca opracuje umowę, w której będę się zobowiązywał do niekorzystania z prawa przewidzianego w tym artykule. Tak jak w innym tekście umowy przekazanej mi do podpisu mam się zobowiązać do niepublikowania w przyszłości utworu będącego rozwinięciem tego, który jest przedmiotem umowy, co jest wyrazistym dowodem, iż niektórzy wydawcy są sabotażystami rozwoju badawczego i w interesie społecznym powinno się przewidzieć może nawet kryminalizację takich żądań. Czemuż się zresztą dziwić, jeśli w tej samej umowie licencyjnej oczekuje się ode mnie oświadczenia, 
że nie będę wykonywał autorskich praw osobistych dotyczących zachowania integralności utworu będącego przedmiotem umowy oraz tego, że w zakresie nieuregulowanym umową nie będę wykonywał nadzoru nad sposobem korzystania z mojego dzieła² .

II. Wydawca zawsze ustala wymogi dotyczace przekazywanych mu tekstów. Nie tylko, co prawie zawsze zrozumiałe ${ }^{3}$, określające dopuszczalna objętość. Także sposób oznaczania części, wyjątkowo (zdarzyło mi się to dwukrotnie) nawet treść, częściej zaś formę zapisu tytułu artykułu, w szczególności zaś powoływania pozycji bibliograficznych w przypisach. Tu żądania są niekiedy przedziwne. Poważny prawniczy edytor nakazuje niemiecka moda, wattpliwej wartości, numerowanie powoływanych prac. Inny żąda nazwisk autorów pisanych rozstrzeloną czcionką (choć nie ma to żadnego, poza estetycznym,

\footnotetext{
${ }^{2}$ Jak zauważa J. Banasiuk: „przyjęcie ograniczonej rozporządzalności autorskimi prawami osobistymi może rodzić pewne niebezpieczeństwa w postaci dalszego osłabiania twórcy w stosunku do zdecydowanie silniejszej pozycji wydawcy. Jest to widoczne w przypadku umów wydawniczych zawieranych w celu stworzenia pracy naukowej. Wydawca niejednokrotnie wymusza na twórcy uzyskanie szerokiej swobody w zakresie decydowania o wykonywaniu autorskich praw osobistych, przede wszystkim w odniesieniu do prawa do integralności dzieła oraz uchylenia możliwości sprawowania kontroli nad sposobem korzystania z utworu przez twórcę, wykorzystując jego słabszą rynkowo pozycję" (idem, Wspóttwórczość i jej skutki w prawie autorskim, Warszawa 2012, s. 310-311). Warto dodać, że pozycja autora będącego badaczem jest słabsza nie tyle rynkowo, co sytuacyjnie: najczęściej nie liczy on na honorarium, które jeśli jest, to znikome, ale ma nadzieję na absurdalne punkty, wymogi dotyczące otwarcia przewodów etc. W recenzji przywołanej monografii J. Sobczak dodaje, że stanowisko „to wpisuje się bardzo mocno i wyraźnie w publicystyczne dyskusje, w których zabierający głos starają się wykazać, że twórca nie powinien domagać się ochrony swoich praw tak osobistych, jak i majątkowych, gdyż przecież działa niejako w interesie społecznym, dla ogółu, wykorzystując możliwości, które dał mu pracodawca, zatrudniając go w instytucji naukowej bądź wyższej uczelni. Wywodzi się z tego, że twórca tego typu dzieła nie powinien się domagać ochrony swoich praw osobistych, a tym bardziej majątkowych. Stanowiska takie, prezentowane wprawdzie zasadniczo jedynie w publicystyce, ale także w poważniejszych dziennikach i czasopismach, maja charakter niezwykle populistyczny i z akceptacja sa przyjmowane przez ogół społeczeństwa, w szczególności przez rzesze internautów i studentów" (idem, Recenzja pracy J. Banasiuk, Wspóttwórczość i jej skutki w prawie autorskim, „Państwo i Prawo” 69, 2014, z. 7, s. 117). Zob. nadto J. Mazurkiewicz, „Cześć, prywatność i zgon pilnie sprzedam!” Wokót dopuszczalności rozporzqdzania prawami osobistymi, w: A. Olejniczak et al. (red.), Wspótczesne problemy prawa zobowiqzań, Warszawa 2015, s. 432 i n.

${ }^{3}$ Moja habilitacja miała zostać opublikowana przez renomowane wydawnictwo prawnicze. Dziekan mojego Wydziału szczodrze wygospodarował odpowiednie fundusze na dotację. Wydawnictwo przez ponad miesiąc analizowało przesłany tekst. Po czym zawarło ze mną umowę. Po kolejnym miesiącu odebrałem na ulicy telefon z poleceniem skrócenia rozprawy o połowę, czyli o 800 stron. Nie podziękowałem za tę propozycję, stać mnie było tylko na taką powściagliwość, że wyłączyłem telefon. Zamiast w twardej oprawie i z tytułem wydrukowanym połyskliwymi literami wydałem swą książkę tak, jak chciałem, choć w kartonowej okładce, w wydziałowym wydawnictwie elektronicznym. Każdy może tu za darmo sprawdzić, czy rzecz warta była edycji w całości: Non omnis moriar. Ochrona dóbr osobistych zmartego $w$ prawie polskim, Wrocław 2010, ss. 904, http://www.bibliotekacyfrowa.pl/dlibra/publication/28001?tab=1. Oczywiście, nie dostałem za nia ani grosza, ale nie żałuję, przeciwnie: zadowolony jestem, że obroniłem owoc kilkudziesięciu lat swojej ciężkiej pracy. Nie chodziło mi tylko o moją książkę, ale o moje samopoczucie. Po pół roku od opublikowania rozprawy B. Górna, kierowniczka naszej wydziałowej biblioteki, zwróciła mi uwagę, że z licznika wejść na stronę, na której ta książka jest dostępna, wynika, że nigdy nie byłaby tak czytana czy przeglądana, gdybym uległ edytorskiemu molochowi.
} 
racjonalnego uzasadnienia), często wymaga się, być może estetycznie usprawiedliwionego, zapisu tytułów kursywa, co niekiedy, w przypadkach kiepsko zorganizowanych i marnie wyedukowanych redaktorów albo - jak słyszę poddanych presji absurdalnych zasad (scilicet: wymysłów) edytorskich prowadzi do efektów śmiesznych, gdy kursywą publikowany jest tytuł artykułu z wyjątkiem wyrazów, które w oryginale tytułu są napisane właśnie kursywą. Niekiedy instruuje się mnie, abym także w tekście, nie tylko w przypisach, posługiwał się wyłacznie inicjałami imion. Nawet wtedy, gdy rozpoczynam zdanie, wskazując autora i - nauczony, że nie wypada zacząć zdania od inicjału imienia - tłumaczę powody, które z trudem przekonują. Jedni nową moda nakazują konieczność rezygnacji z akapitów, inni żądają podawania w przypisach wydawcy przywoływanej publikacji, choć nikomu, poza wydawcami, nie jest to potrzebne.

Znam wyniosłą (tylko wobec osób z tytułem niższym niż doktor habilitowany) panią redaktor, która z trudem znosi przypisy nieco dłuższe, a długich nie cierpi i nie toleruje. Nie mam do niej pretensji, odkąd wiem, jakie ma wykształcenie, a w szczególności od czasu, gdy świeżo upieczony profesor pewnej Alma Mater, gość recenzent w przewodzie doktorskim, z wymownym uśmiechem oświadczył na publicznej obronie we Wrocławiu, że doniosłą wartość recenzowanej przez siebie rozprawy upatruje w znikomej ilości przypisów. Nie widział w tym nic zdrożnego, był wyraźnie zadowolony z tego, co powiedział... Pomyślałem, że czas umierać.

W zwyczajowo poniewieranym Peerelu, ojczyźnie mego dzieciństwa i wieku dojrzałego, uniwersyteccy edytorzy byli dla mnie niczym miód. Przynosiłem im teksty pisane nieporadnie na „Erice”, maszynie do pisania z hitlerowskich jeszcze czasów, bo zawierała klawisz z symbolem SS. Żadnych poleceń z redakcji nie otrzymywałem, ciężko więc pracowano nad moimi młodzieńczymi elaboratami, lecz nie poniewierano mna, nie naruszano moich autorskich praw osobistych (co do praw majątkowych w głowie nikomu nie mieściło się wtedy, że mogą honorarium nie zapłacić), życzliwie doradzano, pytano nawet o język, w którym ma być przez redakcję sporządzone streszczenie (teraz żałuję, że nie poprosiłem o chińskie, poprzestając na francuskim i rosyjskim). Potem przemiła tłumaczka deliberowała nad moimi uwagami i zmieniała, czego żądałem, nр. неродившийся ребенок па зачатый ребенок, prosząc jedynie, bym jej powiedział, w czym różnica, co czyniłem chętnie, bo różnica jest, i to doniosła.

III. Jesteś twórca, ale musisz ukryć swoją emocjonalną tożsamość. Bo emocje są rzekomo be, tak jak gdyby poza emocjami, które obezwładniaja, nie było emocji, które uskrzydlają.

W artykule po trosze pożegnalnym ${ }^{4}$ pisałem o projektach reformy polskiego prawa rodzinnego przygotowanych we współpracy także z Jerzym Strzebinczykiem. I gdy powtarzając często jego nazwisko, uznałem raz jeden za potrzebne ograniczyć się - w kontekście, który nie pozostawiał cienia wątpliwości, o kogo

${ }^{4}$ J. Mazurkiewicz, „Zanim pomysty nasze sczezna wraz z nami”. O zapomnianych projektach reformy prawa rodzinnego, w: M. Andrzejewski (red.), Kodeks opiekuńczy po wielkich nowelizacjach, Acta Iuris Stetinensis, t. 6, Szczecin 2014, s. 313 i n. 
chodzi - do ciepłego określenia: Jurek, pani redaktor nakazała powrót do urzędowej formy. Tylko dzięki troskliwej pieczy przemiłego redaktora naukowego udało mi się „Jurka” zachować.

Zdaniem większości wydawców i większości redaktorów utwór, gdy jest naukowym, nie może być znakiem osobowości, wrażliwości, emocjonalności badacza, bo to się rzekomo z „naukowością” kłóci. Przypomina mi to, gdy w jednej z recenzowanych przeze mnie, nadzwyczaj wartościowej pracy radzieckiej prawniczki, po przytoczeniu wielu mniej lub bardziej uczonych definicji macierzyństwa autorka w końcu odważyła się na definicję własna. Poetycka $\mathrm{w}$ istocie, najwymowniejszą i jakże prawdziwa, czyli wartościową także naukowo. „Matką - napisała - zaczynasz być w momencie poczęcia twego dziecka, a przestajesz nia być, kiedy przestaje bić twoje serce"s. Jakże dobrze, że poważny wydawca tej książki, pozwolił autorce na szczyptę liryzmu, rzadkość nad rzadkościami w przygnębiających monotonią prawniczych buchach.

IV. W art. 43 ust. 1 pr.aut. przewidziano, że jeśli z umowy nie wynika, iż „przeniesienie autorskich praw majątkowych lub udzielenie licencji nastapiło nieodpłatnie, twórcy przysługuje prawo do wynagrodzenia”. To sformułowanie mogłoby usprawiedliwiać opinię, iż zapłata wynagrodzenia także twórcy dzieła naukowego jest zasada, tak jak było to również w praktyce w czasach PRL.

Ale de facto wartość zasady odpłatności ${ }^{6}$ jest dzisiaj $^{7}$ zerowa: wynagrodzenie za przeniesienie autorskich praw majątkowych lub udzielenie licencji do utworu naukowego jest bowiem wyjątkiem, nieodpłatność - zasadą. Przy tym prawie wszyscy badacze prawa autorskiego, na pozór zawsze poprawnie i zawsze poprawnościowo, wskazują na podstawę normatywną dopuszczalności darmowego rozporządzania tymi prawami ${ }^{8}$, nie opatrując tej konstatacji najmniejsza krytyczną refleksja.

Wiadomo, że po odrodzeniu się drapieżnej formy polskiego kapitalizmu znikły ograniczenia w autorsko-edytorskiej zasadzie swobody umów ${ }^{9}$, ale twórca,

${ }^{5}$ Zob. J. Mazurkiewicz, Recenzja pracy A. M. Nieczajewej, Prawowaja ochrana dietstwa w SSSR, „Państwo i Prawo” 44, 1989, z. 11, s. 137.

${ }^{6}$ Zob. np. K. Włodarska-Dziurzyńska, Wynagrodzenie z tytułu przeniesienia autorskich praw majatkowych do utworu, w: T. Targosz, K. Włodarska-Dziurzyńska, Umowy przenoszqce autorskie prawa majatkowe, Warszawa 2010, s. 231; M. Kępiński, Umowy prawa autorskiego, w: System prawa prywatnego, t. 13: Prawo autorskie, red. J. Barta, Warszawa 2013, s. 649-650; D. Sokołowska, Prawo twórcy do wynagrodzenia w prawie autorskim, Poznań 2013, s. 381 i n. oraz powołane tam piśmiennictwo; J. Szyjewska-Bagińska, w: E. Ferenc-Szydełko (red.), Ustawa o prawie autorskim i prawach pokrewnych. Komentarz, Warszawa 2014, s. 339.

${ }^{7}$ Właśnie minęło czterdzieści lat, gdy w „Ruchu Prawniczym, Ekonomicznym i Socjologicznym” (36, 1974, z. 4, s. 147-161) opublikowano mój artykuł Dopuszczalność sqdowego ustalania ojcostwa dziecka poczętego. Zapłacono mi wtedy godziwe honorarium. Po raz pierwszy i - jak się okazuje - ostatni w RPEiS raz. O co nie mogę mieć pretensji, bo tak jak miliony Polek i Polaków (tyle że od dziesiątego roku życia) starałem się obalić ówczesny ustrój. I w końcu obalił się nam. Ale nie w tę stronę, co chciałem...

${ }^{8}$ Zob. np. J. Barta, R. Markiewicz, w: J. Barta et al., Prawo autorskie i prawa pokrewne. Komentarz, Kraków 2005, s. 400; J. Barta, R. Markiewicz, w: iidem (red.), Prawo autorskie i prawa pokrewne. Komentarz, Warszawa 2011, s. 314.

${ }^{9}$ Zob. np. M. Czajkowska-Dąbrowska, Prawo do wynagrodzenia autorskiego i kryteria ustalania wysokości wynagrodzenia w orzecznictwie Sqdu Najwyższego, w: Studia i analizy Sadu 
który i wcześniej był z natury rzeczy słabszą strona, stał się jeszcze słabszy, nierzadko prawie bezsilny. Nikt chyba nawet nie rozważa zgodności z Konstytucją RP pozbawiania wynagrodzenia twórcy dzieła naukowego, gdy z Ustawy Zasadniczej, mimo oczywistego niedostatku ogólnej regulacji expressis verbis, wynika jednak, pozostająca pod ochroną RP przynajmniej minimalna wysokość wynagrodzenia za pracę (zob. art. 65 ust. 4, a także 24 zd. 1, nadto art. 33 ust. 2). Któż dziśs (poza Dorotą Sokołowska, która w chyba w osamotnieniu reprezentuje daleko dalej idące, moim zdaniem poprawne normatywnie i moralne, stanowisko ${ }^{10}$ ) powtarza za Andrzejem Szewcem, że zrzeczenie „się prawa do wynagrodzenia [...] może być nieważne, jeżeli jest sprzeczne z zasadami współżycia społecznego (art. 58 k.c.)"11, choć opinia ta jest przecież po piętnastu latach dużo bardziej usprawiedliwiona powszechnie znanymi okolicznościami ${ }^{12}$.

W umowach, w których udzielam wydawcy licencji wyłącznej do końca ochrony autorskich praw majątkowych, czyli pozbawiam nawet wnuki praw po dziadku, wydawcy każą mi jednak „dla potrzeb podatkowych” oświadczyć, że wartość udzielonej licencji wynosi 300 zł brutto. Nieprzypadkowo wola, żebym udzielił licencji, a nie przeniósł prawa, bo gdy bez trudności wymuszą na mnie licencję wyłączną do końca trwania ochrony autorskich praw majątkowych, sa prawie w takim samym położeniu jak wówczas, gdybym autorskie prawa majątkowe na nich przeniósł. A nie muszą się władzom podatkowym tłumaczyć (o ile w ogóle musza), że wartość przeniesionych praw jest tak niska.

Stanowczość w pozbawianiu twórców naukowych utworów prawniczych prawa do wynagrodzenia idzie w parze z wysokimi, niekiedy bardzo wysokimi cenami nie tylko prawniczych edycji, nierzadko wielokrotnie, niekiedy co-

Najwyższego, t. 5, Warszawa 2011, s. 137. Nadto zob. E. Traple, Umowy o eksploatację utworów $w$ prawie polskim, Warszawa 2010, s. 33 i n.

${ }^{10} \mathrm{Iż}$ „skuteczne zrzeczenie się [...]” prawa do wynagrodzenia za korzystanie z utworu „można uznać [...] za niemożliwe, aczkolwiek niemożliwość ta nie została potwierdzona ustawowo. Pośrednio w art. 44 pr. aut. można dostrzec refleks ujęcia prawa do wynagrodzenia jako niezbywalnego, skoro twórca może domagać się korekty wynagrodzenia w relacjach obligacyjnych, odwołując się do kryteriów wskazanych w tym przepisie” (D. Sokołowska, op. cit., s. 203, zob. także ibidem, przyp. 48 oraz s. 200-202).

11 A. Szewc, Wynagrodzenia twórców i wykonawców w prawie autorskim $i$ wynalazczym, Sopot 1999, s. 175. Por. jednak wymowną interpretację, która i w tamtych czasach była zapowiedzia tego, co jest dzisiaj reguła, choć poprawnościowo rezygnację z wynagrodzenia rzadko określa się dziś dosadnym wyrazem „zrzeczenie” (J. Błeszyński, w: idem, M. Staszków, Prawo autorskie i wynalazcze, Warszawa 1983, s. 140: „uprawnienie do wynagrodzenia ma charakter iuris cogentis. Wynika z tego, że nie może być przedmiotem zrzeczenia się. Zrzeczenie się może natomiast mieć miejsce w odniesieniu do wynagrodzenia należnego z konkretnego tytułu prawnego"; zob. także J. Błeszyński, Prawo autorskie, Warszawa 1985, s. 128).

12 Zob. np. E. Traple, op. cit., s. 60: „Postanowienia wyłączające prawo do wynagrodzenia występują w przypadku wydawania różnego rodzaju ksiąg pamiątkowych, wydawnictw jubileuszowych, wykonań w czasie imprez, z których dochód ma być przeznaczony na cele charytatywne. Reguła wynikająca z art. 43 ust. 1 pr. aut. nie budzi w praktyce specjalnych wątpliwości”. Jak wiadomo, pozbawianie wynagrodzenia dotyczy nie tylko autorów publikujących czy wykonujących utwory we wskazanych okolicznościach. Natomiast opinia, że ów proceder w praktyce nie budzi „specjalnych wattpliwości”, jest dla mnie wyrazistym potwierdzeniem nie mizerii, ale nędzy ochrony prawa do wynagrodzenia przewidzianej w prawie autorskim oraz postawy prawie wszystkich badaczy prawa, którzy najwyraźniej nie dostrzegają niemoralności takich praktyk edytorów. 
rocznie wznawianych, zapewniających wydawcom duże i stałe dochody, które uzupełniaja krocie uzyskiwane z wydań aktów prawnych, gdzie trud edytorski jest znikomy, elementy twórcze najczęściej groteskowe, swoboda darmowej eksploatacji wydawanych tekstów oczywista.

V. Z tego, że wydawanie utworów jest przede wszystkim działalnością gospodarcza, nie wynika supozycja, aby los utworów naukowych i samych uczonych wydać na pastwę wolnego rynku. Ten kieruje się wyłącznie zyskiem, a to nie zawsze sprzyja rozwojowi nauki, niekiedy szkodzi.

Edytorzy, jak widać, skutecznie forsują swoje cele również wtedy, gdy zabiegaja, jak się to niekiedy zdarzało, o wydłużenie ochrony autorskich praw majątkowych, co rodzi u niektórych naiwne przypuszczenie, że chodzi im o interesy spadkobierców twórcy ${ }^{13}$. Jest we mnie intuicyjne bardziej niż udowodnione przeświadczenie, że także wyśmienicie zorganizowana zapobiegliwość o unormowanie statusu umożliwiającego edycje utworów rzekomo osieroconych więcej ma wspólnego z zyskiem wydawców niż z troską o rozwój kultury i nauki. Gdzie indziej, także na niszowych obszarach rynku wydawniczego, widać edytorski etos tych, którzy - marząc o kolejnym ACTA i zabiegając o ochronę już swoich (po ich nabyciu) praw autorskich przed eksploatacja przez nieuprawnionych w Internecie - wspieraja innych, którzy w Paryżu, Londynie czy Nowym Jorku kupują tani bilet do Bamako, tam do wynajętego dżipa każa pakować worki z najtańszym ryżem i solą po to, by w odległych wioskach dokonywać za te niby-podarunki nagrań, które potem, po powrocie do metropolii, w sklepach z world music, sprzedawać będą za ceny, o których nigdy nie marzyli malijscy, czadyjscy czy nigerscy artyści ludowi. I o takim neokolonializmie pisała w mądry sposób w swych prawie zawsze krótkich i nierzadko urokliwych artykułach nieoceniona Maria Poźniak-Niedzielska ${ }^{14}$.

VI. Wypominając w tytule artykułu nędzę prawa autorskiego, odnoszę ją do problemu na początku tego właśnie tytułu wskazanego. Nie brakuje bowiem norm prawa autorskiego, które skutecznie strzegą czyichś interesów, np. wydawców. Zresztą i wydawca wydawcy nierówny, są i tacy, którzy nieprzytłoczeni żądzą zysku sa spolegliwi uczonym, nietoksyczni. O nich tylko wspominam, tu zaś ukazać chcę to, co czynią inni: co martwi, niepokoi, nierzadko badaczy obraża. Co zresztą nie odnosi się tylko do edytorów. Bo i stowarzyszenia twórców właściwe ze względu na rodzaj twórczości lub organizacje zbiorowego zarządzania prawami autorskimi lub prawami pokrewnymi, które zarządzały za życia prawami autorskimi zmarłych twórców, mimo jasnej legitymacji w art. 78 ust. 4 pr.aut., nigdy się w Polsce nie wstawiły za poniewieranymi nieraz autorskimi dobrami osobistymi zmar-

\footnotetext{
${ }^{13}$ Zob. w szczególności D. Flisak, Wydtużenie okresu ochrony praw pokrewnych, czyli jak $z$ poważnego tematu uczynić groteskę, „Zeszyty Naukowe Uniwersytetu Jagiellońskiego. Prace z Prawa Własności Intelektualnej” 2009, z. 105, s. 76 i n., a nadto J. Mazurkiewicz, Kapitalizm..., s. 297-298 i piśmiennictwo przywołane w przyp. 47.

${ }_{14}$ Zob. M. Poźniak-Niedzielska, Problemy ochrony folkloru $w$ prawie autorskim, „Państwo i Prawo" 25, 1970, z. 8-9, s. 325 i n.
} 
łych twórców ${ }^{15}$. Czyż to nie świadczy in casu o nędzy tego prawa, jeśli jest tak ukształtowane, że ci, którzy z twórców żyją i dla twórców istnieja, za nic mają los ich dóbr osobistych po śmierci?

VII. Twórczość, także naukowa, i dzisiaj ogranicza cenzura, wobec której instrumentarium prawa autorskiego nigdy nic nie znaczyło i nie znaczy. Nie ta niby-cenzura, która słusznie powściaga przed naruszaniem cudzych dóbr osobistych, np. uczuć religijnych, choć i tutaj dochodzi sporadycznie do watpliwych nadinterpretacji ${ }^{16}$.

Podobnie jak niegdyś, najgroźniejszą dla społecznej wiedzy oraz nauki, nie wyłączając nauki prawa, jest cenzura dotyczacca ujawnienia prawdy o zjawiskach politycznych, ekonomicznych, finansowych, zdrowotnych, ochrony środowiska, militarnych i kryminalnych, wtedy gdy te niosa ze sobą zagrożenia dla ludzkości, praw człowieka, choćby i tylko Konstytucji RP.

Nie jest to już, co oczywiste, cenzura państwowa, ale sprywatyzowana cenzura redaktorów, wydawców, różnorakich kapitałodawców, niekiedy nawet recenzentów. Nie mniej, a niekiedy nawet bardziej skuteczna niż nie tak dawna cenzura urzędowa. Cicha, bez wskazywania ocenzurowanych miejsc i podawania nieistniejącej przecież podstawy prawnej, bez dostarczania cenzurowanemu autorowi szczątkowej satysfakcji ${ }^{17}$.

${ }^{15}$ Zob. J. Mazurkiewicz, Non omnis moriar..., np. s. 147. Warto tu wspomnieć i o tym, że gdy gdzie indziej ustawodawca wyraził pozornie jednoznaczną troskę o ochronę wybranych dóbr osobistych Fryderyka Chopina, w rzeczywistości okazała się ona farsą i de facto tylko zmonopolizowała komercyjną eksploatację nazwiska i wizerunku Chopina. Znaną historię z udanymi staraniami o ulokowanie w rządowym projekcie nowelizacji ustawy o radiofonii i telewizji zwrotu „lub czasopisma” warto porównać z do końca udanym ukształtowaniem art. 10 ust. 2 ustawy z 3 lutego 2001 r. o ochronie dziedzictwa Fryderyka Chopina (Dz. U. Nr 16, poz. 168), jednoznacznym, wymownym i niebudzącym chyba, poza mna, niczyjej krytyki (zob. J. Mazurkiewicz, Non omnis moriar..., s. 760 i n.).

${ }_{16}$ Tak było z wyśmienitym antywojennym billboardem autorstwa K. Kozyry, przedstawiającym po jednej przekątnej dwie leżące na boku, nagie, ale w żadnym razie nie obsceniczne, postacie niewieście (jedną z nich jest ta wybitna artystka, druga - jej siostra). Po drugiej przekątnej umieszczone zostały symbole w istocie czerwonokrzyskie, a nie religijne, wskazujące na wszystkie siły biorące udział w tragedii Jugosławii rozdrapywanej na kawałki własnymi rękami, choć przy intensywnym wsparciu obcych. Był to krzyż (w czerwonokrzyskiej formule taki sam dla chrześcijan wschodnich i zachodnich) oraz półksiężyc (wtedy jeszcze tylko muzułmańskich Bośniaków, potem także Albańczyków i tzw. Kosowarów, którzy niczym przyszli Prusacy po wymordowaniu Prusów postanowili przyjąć za swoją nazwę społeczności ogniem i mieczem wyrugowanej z ojcowizny).

${ }^{17}$ Kilka moich artykułów ogłoszonych w „Tygodniku Powszechnym” opublikowano z czytelnymi śladami interwencji cenzury: kwadratowymi nawiasami i podaną podstawa prawną cenzorskiej ingerencji (są one pośród moich publikacji, których wykaz zmuszony byłem przygotować na użytek przewodu habilitacyjnego i który, uzupełniany, znajduje się na: http://prawo.uni.wroc.pl/ user/12132). W ogóle nie chodziło w tych artykułach o wielką politykę, o tej w tamtych artykułach nie pisałem. Najwymowniejszym przykładem był artykuł ogłoszony na łamach dolnośląskiego pisma religijnego. Włączyłem się nim w spór dotyczący tego, czy w Centrum Zdrowia Matki Polki mogą być dokonywane aborcje. Podzielając oczywiste dla mnie argumenty przeciwników zabijania poczętych dzieci, zauważyłem jako prawnik, że ówczesne prawo dopuszczało jednak tzw. przerywanie ciąży, nie przewidując żadnego wyjątku co do odpowiednio wyposażonego m.in. szpitala, bez względu także na jego nazwę. Zauważyłem więc, że i w owym Centrum unicestwianie poczętych dzieci będzie legalne, choć względy przyzwoitości przemawiają za zmianą nazwy na „Cen- 
Nawet gdy redaktorzy i wydawcy okażą się spolegliwi i tekst niedobrze widziany przez rządzących ukaże się, tego, kogo mogą uderzyć, czyli autora, może spotkać kara. Nie piszę o przypadku wymyślonym, lecz o znanym kilku osobom na tej sali* polskim uczonym prawniku, który dotkliwie odczuł cenę swego nieprawomyślnego artykułu. W ten sposób skutecznie propagowany jest też mechanizm najtańszej, bo samocenzury.

Jeśli nie tylko utytułowani uczeni nie mogą bezkarnie potykać się z rządzącymi, cóż dopiero liczyć na odwagę młodych adeptów nauki? Takie procedery dotykają bowiem ich przede wszystkim, gdy publikuja samotnie, bez parasola ochronnego promotora czy mistrza. To, czego wtedy doświadczaja, uczy ich już na początku badawczej drogi ostrożności, buduje mechanizm intelektualnego i emocjonalnego asekuranctwa, często nawet bojaźń, nakazując poprawność, czyli to, co dla nauki jest równie zabójcze, jak głupota. Choć, chwała Bogu, zdarzają się i tu wyjątki, o czym wspominam w Poznaniu, na Uniwersytecie wydajacym szacowny „Ruch Prawniczy, Ekonomiczny i Socjologiczny”, $\mathrm{z}$ uznaniem.

Przed laty napisałem z gronem nie tylko doktorantów artykuł, który nie mógł się rządzącym podobać. Unaoczniał bowiem i dokumentował powszechne łamanie jednego z podstawowych praw człowieka gwarantowanych także w Konstytucji RP. Przez dwa lata zwodzono nas w redakcji, zaczynając od pisemnej deklaracji zgody na druk, poprzez „trudności redakcyjne”, do ostatecznego „nie opublikujemy”. Nie musiałem zadawać sobie trudu, by uwiarygodnić powody, dla których tak się stało. Pisząc o tym w grudniu 2014 r., żywię nadzieję, że po kilku latach peregrynacji ów tekst gdzie indziej ujrzy światło dzienne ${ }^{19}$, czym, jestem tego pewien, rządzący nie zanie-

trum Zdrowia Matki Polki Abortującej Się”, co oczywiście wywołało ingerencję cenzury i co dzisiaj każdy może sprawdzić, jeśli zada sobie trud wertowania bibliotecznych zbiorów periodyków (zob. J. Mazurkiewicz, Matka Polka pójdzie na „zabieg?”, „Nowe Życie” 1989, nr 2, s. 12-13).

* Pierwotna wersja artykułu została przedstawiona podczas konferencji „20 lat ustawy o prawie autorskim i prawach pokrewnych”, Poznań, 20 listopada 2014 r. (przyp. red.).

${ }^{18}$ W „Ruchu Prawniczym, Ekonomiczny i Socjologicznym” 68, 2006, z. 1, s. 139-154 opublikowany został artykuł radcy prawnego M. M. Malinowskiego zatytułowany Amerykańska operacja militarna $w$ Afganistanie a prawo panstwa do samoobrony. $\mathrm{Z}$ tytułu widać, że autor i być może redakcja pogodzili troskę o wierność prawdzie z wymogami kamuflażu wymagającego posługiwania się niekiedy eufemizmami. Wnioski sformułowane przez autora na s. 153 nie pozostawiaja jednak cienia wątpliwości, jak należy oceniać tamtą wojnę napastniczą oraz okupację (w której udział wzięło również polskie wojsko), trwająca ponad dwukrotnie dłużej niż druga wojna światowa. Nieco inaczej, po literacku chytrzej, rozwiązywali podobne dylematy redaktorzy „Tygodnika Powszechnego" w czasach wcześniejszej radzieckiej wojny w Afganistanie. Na pierwszej stronie pisma znajdowała się wąska i długa na całą szpaltę rubryka, w której podawano jednozdaniowe informacje, najczęściej polityczne. I choć tygodnik ten poddawany był nadzwyczaj wnikliwej analizie cenzorów, ale jednak udało się, może nie bez wyrozumiałej postawy tych ostatnich, opublikować tu wiadomość o treści: „Według wiadomości napływających z Afganistanu spokój panuje w Kabulu". Z czego jasno wynikało, że poza afgańską stolica trwa wojna. Dzisiaj, w czasach nie tylko natowskiej agresji na ten biedny i dumny kraj, takiej wiadomości nie można już opublikować bez narażenia się na zarzut oczywistego fałszu: spokoju nie ma tam nigdzie, w Kabulu w szczególności. Historia magistra vitae pod warunkiem, że chcesz widzieć, słyszeć, rozumieć.

${ }^{19}$ Artykuł ten właśnie ukazał się, zob. M. Andreasik et al., Orwell $w$ realu, czyli o systemie Echelon z perspektywy polskiego prawa, „Studia Prawnicze. Rozprawy i Materiały” 2014, nr 2, s. 55 i n. 
pokoją się, jeśli najwyraźniej nie niepokoją ich publikowane właśnie zarzuty nieporównywalnie poważniejsze.

Gdy ponad czterdzieści lat temu ukazał się mój debiutancki artykuł prawniczy ${ }^{20}$, zastępca redaktora naczelnego „Palestry” mec. Stefan Mizera poinformował mnie pisemnie, że tekst poddany został zmianom nakazanym przez Główny Urząd Kontroli Prasy, Publikacji i Widowisk. Ale mimo to artykuł asystenta stażysty ukazał się, nie czekał latami tak jak ten, którego jestem współautorem, będąc profesorem Uniwersytetu Wrocławskiego. Tak to koło moich przygód z cenzurą prawie się zamknęło.

Niepotrzebna jest zewnętrzna cenzura, gdy utytułowani i nieutytułowani członkowie redakcji zatroskani o swoje interesy i poinstruowani przez wydawców wiedza, co zostanie nieprzychylnie postrzeżone przez tych, którzy ich zatrudniaja, udzielają im wsparcia, zlecają wykłady, zamawiaja ekspertyzy etc.

Zwłaszcza w ostatnim miesiącu 2014 r., gdy świat znowu obiegła nazwa, zdawałoby się zapomnianych przez Boga, Starych Kiejkutów, uzasadnione jest pytanie o szkody wyrządzane nie przede wszystkim, ale także nauce i jej wiarygodności, przez cenzurę naszych czasów. Nie tylko bowiem karniści zajmujaccy się problematyką zbrodni wszczynania i prowadzenia wojen napastniczych (art. 117 k.k.), zabijania podczas niej cywilów oraz torturowania jeńców (są w Polsce tacy uczeni prawnicy?), nie tylko konstytucjonaliści zajmujaccy się przesłankami decydowania o stanie wojny (art. 116 Konstytucji RP), mogli przecież zabrać krytyczny głos, nie poprzestając na znanych mi publikacjach, które utwierdzić miały w przeświadczeniu, że gwałt na biednych najczęściej narodach, na prawie międzynarodowym, na własnej Ustawie Zasadniczej, nie ma miejsca. Nawet specjaliści od zabezpieczenia społecznego mogliby ukazywać niemoralność przyjmowanych także w polskim prawie rozwiąań, z których wynika, że wdowa po zabitym przez rzezimieszków listonoszu, po uśmierconym przez kłusowników leśniku, po lotniku, który zginął w katastrofie samolotu pasażerskiego, po ratowniku górskim, którego pochłonęła lawina, czy po lekarzu zmarłym po zarażeniu się wirusem eboli, ma o niebo trudniejszą drogę do renty rodzinnej niż ta, której mąż zginąłby od friendly fire podczas „niewłaściwego użycia” ${ }^{21}$ wielokalibrowego karabinu maszynowego oraz moździerza, wskutek czego „przypadkowo spowodowano śmierć” dwóch afgańskich kobiet, w tym ciężarnej, mężczyzny, trojga dzieci oraz ciężko zraniono trzy kobiety uczestniczące w wiejskim weselu w Nangar Khēl ${ }^{22}$.

Ale nie musi chodzić o problemy z najwyższej, czy nawet z wyższej półki. Przed laty podjąłem beznadziejna, jak się okazało, próbę walki z niemoralnym

${ }^{20}$ J. Mazurkiewicz, Nasciturus w prawie cywilnym i karnym, „Palestra” 1973, nr 11, s. 37 i n.

${ }^{21}$ Por. np. (RZ), Zapadt wyrok ws. Nangar Khel. Trzech żotnierzy skazanych, http://wiadomości.onet.pl/kraj/zapadl_wyrok_us_nangarkhel_trzech_zolnierzy_skazanych/ra8tx7 (dostęp: 13.06.2015).

${ }^{22}$ Por. art. 70 ust. $1-4$ ustawy z 17 grudnia 1998 r. o emeryturach i rentach z Funduszu Ubezpieczeń Społecznych (Dz. U. 2015, poz. 748) z art. 24 pkt 1a in fine i pkt 1c in fine ustawy z 10 grudnia 1993 r. o zaopatrzeniu emerytalnym żołnierzy zawodowych oraz ich rodzin (Dz. U. 2015, poz. 330). Za wskazanie mi dawno temu tego problemu i tych unormowań, zanim zaczęli o nich mówić sami najdotkliwiej zainteresowani, dziękuję Marysi i Zosi Zaporowskim. Za troskliwą pieczę nad całym artykułem dziękuję, jak zawsze, Basi Bernfeld. 
i bezsensownym sposobem egzaminowania osób ubiegających się o aplikacje prawnicze. Organizując międzynarodowa konferencję, miałem naiwną nadzieję na rozpoczęcie przynajmniej środowiskowej debaty. Konferencja ta wywołała co prawda odzew w postaci kilkunastu interpelacji poselskich, wzbudziła osobiste zainteresowanie ministrów sprawiedliwości Czech i Bułgarii oraz ministerstwa sprawiedliwości Białorusi, lecz najbardziej zainteresowany, czyli polski minister sprawiedliwości, w ogóle nie zareagował na przesłane mu zaproszenie. I to skłoniło przede wszystkim młodych uczestników konferencji do napisania orędzia, na które w końcu, przyparty do muru, odpowiedział, w części pokrętnie, w części nieprawdziwie, wyłącznie broniąc tego, co niesprawiedliwe, bezsensowne i niemoralne. Przygnębieni lektura jego odpowiedzi nie tylko młodzi adepci prawa napisali odpowiedź ${ }^{23}$ na odpowiedź, która tak jak reszta dorobku tej konferencji, dostępna jest w monografii opublikowanej także w Internecie, dostępnej tu bez opłat ${ }^{24}$. Wspominam o tym, kończąc swój artykuł, nie bez powodu. Otóż, kilku z tych młodych autorów, aplikantów i kandydatów na aplikantów, podpisało się pod swoją odpowiedzią pseudonimami. Tłumaczyli mi się, że nie wiedza, czy nie spotka ich kara za to, co napisali...

Jeśli młodzi prawnicy, dobrze, że nie wszyscy, mają już we krwi bojaźń, co czeka nas wszystkich, w tym działalność instytucji służących ochronie prawa oraz naukę prawa w Polsce?

dr hab. Jacek Mazurkiewicz

Profesor Uniwersytetu Wroctawskiego

jjmaz@prawo.uni.wroc.pl

\section{ON THE OBJECTIFICATION OF AUTHORS, THE OMNIPOTENCE OF PUBLISHERS AND THE POVERTY OF INTELLECTUAL PROPERTY RIGHTS. \\ INTELLECTUAL PROPERTY RIGHTS DURING THE RESTORATION OF CAPITALISM IN POLAND}

Sum mary

Scholars of intellectual property rights in Poland have described the manifold commercial and personal rights of authors and their protection. Yet they have essentially written nothing about the deprecation or even annihilation of many of those rights during the restoration of predatory capitalism. About the often fictitious right to royalties. About how not only the form of texts was forced on authors. About the not infrequent censorship of articles concerning politically delicate issues. These procedures mainly affect young scholars, teaching them servility, often generating fear and compliance rather than fidelity to the truth and to values. Not only science is being strangled in this way.

${ }^{23}$ A. Bogut et al., Nieprawda, Panie Ministrze! Nasza odpowiedź na odpowiedź Ministra Sprawiedliwości, w: J. Mazurkiewicz (red.), Egzamin powinien mieć sens i być sprawiedliwy. O egzaminowaniu studentów prawa, kandydatów na aplikantów, aplikantów, doktorantów i innych prawników. Konferencja międzynarodowa, 14 grudnia 2012 r., Wrocław, Wrocław 2013, s. 289 i n.

${ }^{24}$ Zob. http://www.bibliotekacyfrowa.pl/publication/40555. 